\title{
Multiple Sclerosis and Subsequent Human Immunodeficiency Virus Infection: A Case with the Rare Comorbidity, Focus on Novel Treatment Issues and Review of the Literature
}

\author{
CHARALAMPOS SKARLIS ${ }^{1}$, MARIA GONTIKA ${ }^{1}$, SERAFEIM KATSAVOS ${ }^{1}$, \\ GIORGIOS VELONAKIS ${ }^{2}$, PANAGIOTIS TOULAS ${ }^{2}$ and MARIA ANAGNOSTOULI ${ }^{1,3}$ \\ ${ }^{1}$ Immunogenetics Laboratory, 1st Department of Neurology, \\ Medical School of National and Kapodistrian University of Athens, Aeginition Hospital, Athens, Greece; \\ ${ }^{2}$ Research Unit of Radiology and Medical Imaging, 2nd Department of Radiology, \\ Medical School of National and Kapodistrian University of Athens, Eugenidion Hospital, Athens, Greece; \\ ${ }^{3}$ Outpatient Section of Demyelinating Diseases Clinic, 1st Department of Neurology, \\ Medical School of National and Kapodistrian University of Athens, Aeginition Hospital, Athens, Greece
}

\begin{abstract}
Background: The comorbidity between Multiple Sclerosis (MS) and Human Immunodeficiency Virus (HIV) infection is particularly rare. Only a few cases of comorbidity of Clinically Definite(CD)-MS and HIV have been documented worldwide, while the potential beneficial role of antiretroviral therapy regarding MS activity has long been an area of debate. Case Report: We present a 36-year old male, bearing a diagnosis of CD-MS for twelve years. $H e$ had been treated for ten years with interferon-beta-1b, when he voluntarily discontinued therapy, claiming clinical stability. One year later he was diagnosed positive for HIV and he started and continued only on efavirenz/emricitabinel tenofovir-disoproxil fumarate (ATRIPLA $\left.{ }^{\circledR}\right)$, remaining relapse-free until today. Conclusion: This fact, in combination with the unique pharmaceutical composition of the drug, which contains a component similar to a newlyapproved agent for $M S$, dimethyl fumarate, prompted us to review the literature regarding this rare comorbidity and to suggest that the role of the antiretroviral therapy should be further explored in MS.
\end{abstract}

This article is freely accessible online.

Correspondence to: Ass. Prof. Maria C. Anagnostouli, Demyelinating Diseases Clinic \& Director of Immunogenetics Laboratory, 1st Department of Neurology, Medical School, National and Kapodistrian University of Athens, Aeginition Hospital, 72-74 Vassilisis Sofias Ave, 11528, Athens, Greece. Tel: +30 2107289278, Fax: +30 2107216474, e-mail: managnost@med.uoa.gr

Key Words: Multiple sclerosis, HIV, antiretroviral therapy, ATRIPLA ${ }^{\circledR}$, neuroinflammation.
Multiple sclerosis (MS) is a chronic inflammatory autoimmune disease of the central nervous system (CNS), resulting in demyelination and subsequent degeneration of the axons, affecting mainly the white, but also the gray matter (1). The neurologic complications of Human Immunodeficiency Virus (HIV) have been reported since 1982 and it has been proven that CNS constitutes a major target of the HIV (2-4). In particular, neuroinflammation and demyelination have been suggested as mechanisms causing both HIV-1-associated neurocognitive disorder (HAND) and HIV encephalopathy (HIVE) $(5,6)$.

The coexistence of demyelinating neurological disorders and HIV is particularly rare, especially regarding MS. Here we report the case of a patient bearing a diagnosis of clinically definite-MS (CDMS) for twelve years, who was recently diagnosed positive for HIV infection. He was started on efavirenz/emricitabine/tenofovir disoproxil fumarate (ATRIPLA ${ }^{\circledR}$ ) and remained relapse-free, without receiving any pharmacological therapy for MS. To our knowledge, this is the first case of MS-HIV comorbidity treated with this novel antiretroviral compound.

\section{Case Report}

This is a 36-year-old white male and a known case of multiple sclerosis diagnosed 12 years ago, at the age of 24 years old. At that time, in 2003, he experienced two distinct neurological clinical attacks during a four-month period. The first attack consisted of numbness of the lower extremities with a hypoesthesia at thoracic level 3 (T3) and he was evaluated at a province hospital $(\mathrm{PH})$. He did not receive any treatment and the symptoms partially resolved, regarding patient's statement, because we had not examined him that 
time. Four months later, he was hospitalized at the same PH, because of an episode of acute right optic neuritis. His rest neurological examination is referred as normal. He was treated with $1 \mathrm{gr}$ intravenous (IV) methylprednisolone for five days, followed by per os tapering, until total remission. At that time, the performed brain magnetic resonance imaging (MRI) revealed multifocal white matter T2 lesions, without gadolinium enhancement in T1 sequences, fulfilling the McDonald and Barkhof criteria, for Multiple Sclerosis (MS) (7). He refused lumbar puncture; therefore, the oligoclonal band status is still unknown.

The patient visited for the first time the Outpatient Department of our Clinic (OTC) a few months later, in 2004. His personal history was significant for chicken pox at the age of 16 years and childhood asthma. His family history was positive for autoimmune diseases, as his mother bore a diagnosis of Hashimoto's disease. His neurological examination revealed only indifferent bilateral plantar reflexes. He had a full laboratory screening with no pathological results except for high levels of IgG immunoglubin. He repeated brain MRI, which showed a new gadolinium enhanced parietal lesion, thus he initiated treatment with interferon beta- $1 \mathrm{~b}$ three times weekly, with satisfying responsiveness and tolerance.

During the following decade, he experienced two further clinical attacks, with an interval of two years. The first episode, in 2007, consisted of numbness of the upper extremities, with a hypoesthesia level at cervical level 5 (C5), fully remitted after three days of $1 \mathrm{gr}$ IV methylprednisolone followed by per os tapering, at the $\mathrm{PH}$. The second one, in 2009, consisted of left horizontal diplopia, partially improved after per os methylprednisolone treatment. During the second episode, his neurological examination revealed left horizontal diplopia and indifferent bilateral plantar reflex and his Expanded Disability Status Scale (EDSS) score was estimated at 2.00. The new MRI scanning showed non-active multifocal white matter lesions in both the brain and cervical spine, with one new periventricular lesion. In 2012, he voluntarily discontinued therapy, claiming of no symptoms and clinical stability. Until then, his Annualised Relapse Rate (ARR) was 0.44, his EDSS progression 0.22 and he had received three courses of cortisone, either intravenously or per os.

In 2014, he was hospitalized in the $\mathrm{PH}$ for a mild brain injury, after a conflict episode on the road. During his hospital evaluation, his initial blood tests showed white blood cell (WBC) $6.85 \mathrm{~K} / \mu \mathrm{l}$, lymphocytes $(1.69 \mathrm{~K} / \mu \mathrm{l})$ and low platelets $(60 \mathrm{~K} / \mu \mathrm{l})$ and subsequently, he was found positive for HIV. He initiated antiretroviral treatment with efavirenz $(600 \mathrm{mg}) /$ emricitabine $(300 \mathrm{mg}) /$ tenofovir-disproxil fumarate (200 mg) (ATRIPLA ${ }^{\circledR}$ ), one tablet once a day, with satisfying responsiveness. Regarding his MS course, he remained both clinically and neuro-radiologically stable. After eight months on ATRIPLA ${ }^{\circledR}$, his WBC were $7.5 \mathrm{~K} / \mu$ l and his lymphocyte

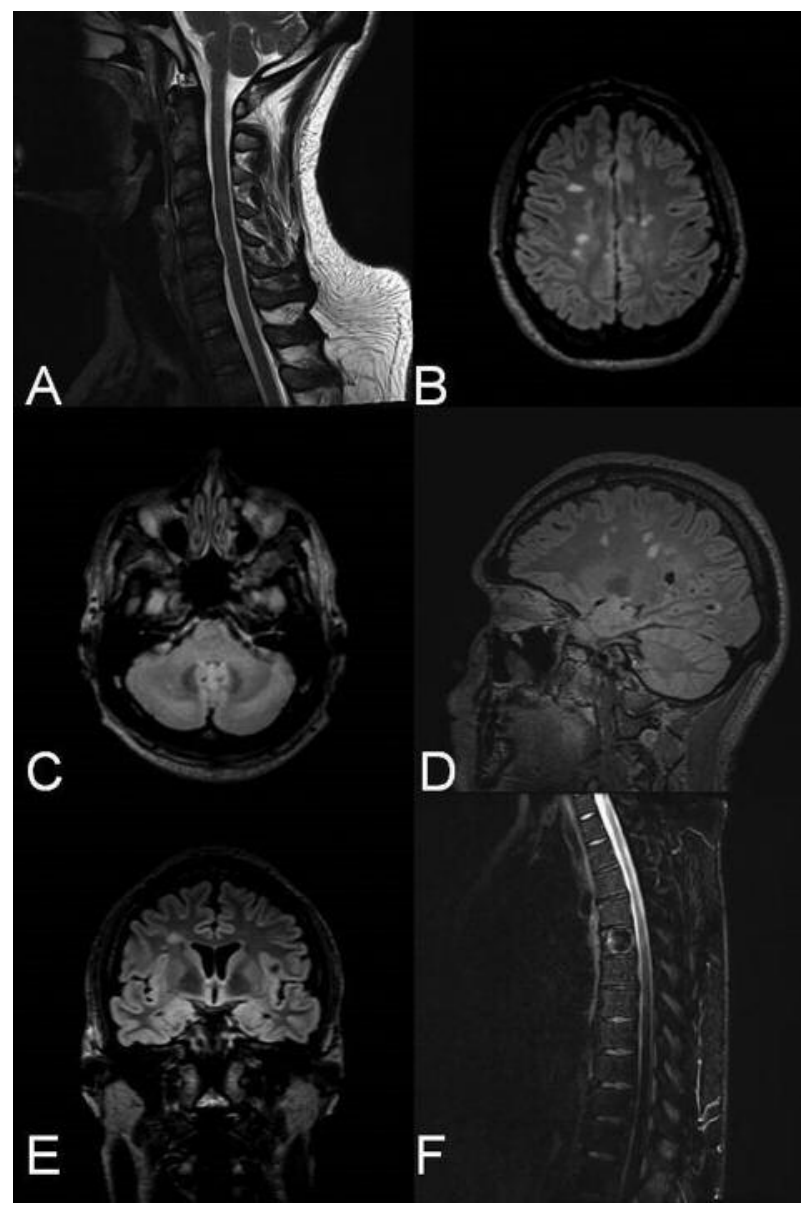

Figure 1. Patient's MRI scans after eight months on ATRIPLA. A. Cervical MRI; Sagittal T2-weighted image reveals hypertensive lesions (C2-C3, C4, C5-C6). B-C. Axial FLAIR (Fluid-attenuated inversion recovery) brain images, with characteristic chronic periventricular and juxtacortical lesions (B), and a cerebellum lesion $(C)$. D. Sagittal FLAIR brain image with hypertensive lesions involving the corpus callosum (Dawson fingers). E. Coronary FLAIR image with right juxtacortical hypertensive lesion. F. Sagittal T2-weighted thoracic MRI, with no apparent intramedullary demyelinating lesions, T5 spinal hemangioma.

number was $1.90 \mathrm{~K} / \mu \mathrm{l}$ and platelets $153 \mathrm{~K} / \mu \mathrm{l}$. His neuroradiological scans were absolutely the same, as well (Figure 1). Today, after almost three years on this antiretroviral therapy, his ARR is 0.28 , his EDSS progression 0.14 , he demonstrates unidentifiable HIV blood-load, and he is fully functional, concerning activities of daily living (Table I).

\section{Literature Review}

The coexistence of demyelinating neurological disorders and HIV is particularly rare, especially regarding MS. In 1989, 
Table I. Milestones of patient's clinical course and therapy.

\begin{tabular}{|c|c|c|c|c|c|c|c|}
\hline & 2003 & 2004 & 2006 & 2007 & 2009 & 2014 & 2015 \\
\hline Relapses & $\begin{array}{l}\text { 1. Numbness of lower } \\
\text { extremities and trunk } \\
\text { 2.Right optic neuritis }\end{array}$ & $\begin{array}{l}\text { Clinically } \\
\text { stable }\end{array}$ & $\begin{array}{l}\text { Clinically } \\
\text { stable }\end{array}$ & $\begin{array}{l}\text { Numbness } \\
\text { of upper } \\
\text { extremities }\end{array}$ & $\begin{array}{l}\text { Left horizontal } \\
\text { diplopia }\end{array}$ & $\begin{array}{l}\text { Clinically } \\
\text { stable }\end{array}$ & $\begin{array}{l}\text { Clinically } \\
\text { stable }\end{array}$ \\
\hline EDSS & Referred as zero & 1.0 & 1.0 & No data & 2.0 & 2.0 & 2.0 \\
\hline Corticosteroids & $\begin{array}{l}5 \text { g Methyl- } \\
\text { prednisolone, } \\
\text { per os tapering }\end{array}$ & ---------- & ---------- & $\begin{array}{l}3 \text { g Methyl- } \\
\text { prednisolone, } \\
\text { per os tapering }\end{array}$ & $\begin{array}{c}\text { Per os } \\
\text { methyl- } \\
\text { prednisolone }\end{array}$ & ----------- & ---------- \\
\hline Brain MRI & $\begin{array}{l}\text { Multiple subcortical } \\
\text { and periventricular } \\
\text { lesions of both } \\
\text { cerebral } \\
\text { hemispheres }\end{array}$ & $\begin{array}{c}\text { One new } \\
\text { active left } \\
\text { parietal lesion } \\
\text { Gadolinium } \\
(+)\end{array}$ & $\begin{array}{l}\text { Multiple } \\
\text { lesions of } \\
\text { the cerebral } \\
\text { hemispheres, } \\
\text { one new } \\
\text { lesion of the } \\
\text { corpus callosum }\end{array}$ & ---------- & $\begin{array}{l}\text { One new peri- } \\
\text { ventricular lesion } \\
\text { Gadolinium (-) }\end{array}$ & ---------- & $\begin{array}{c}\text { T2 sequences } \\
\text { stable } \\
\text { T1 sequences } \\
\text { with some } \\
\text { black holes }\end{array}$ \\
\hline Cervical MRI & --------- & ---------- & $\begin{array}{l}\text { Three-Four intra- } \\
\text { medullary lesions, } \\
\text { mainly at C2-C3 } \\
\text { and C4 levels. } \\
\text { Gadolinium (-) }\end{array}$ & ---------- & Stable & Stable & Stable \\
\hline Thoracic MRI & ---------- & ---------- & --------- & ---------- & ---------- & ---------- & Negative \\
\hline $\begin{array}{l}\text { DMT } \\
\text { HAART }\end{array}$ & ---------- & Interferon-b-beta & Interferon-b-beta & Interferon-b-beta & Interferon-b-beta & $\begin{array}{c}\text { Discontinuation } \\
\text { ATRIPLA }^{\circledR}\end{array}$ & ATRIPLA $^{\circledR}$ \\
\hline
\end{tabular}

DMT, Disease modifying therapy; HAART, high active antiretroviral therapy; EDSS, expanded disability status scale; MRI, magnetic resonance imaging; Gd, gadolinium.

Berger and collaborators were the first to describe a series of seven patients with an MS-like disease and HIV comorbidity $(8,9)$. Taking into consideration the primitive criteria of MS in 1989, we cannot be sure that these patients were suffering from MS per se, or another demyelinating disease. However, six definitive MS-HIV comorbidity cases, according to original and revised McDonald criteria, are presented in the international literature (10-15). In two reports, HIV infection was diagnosed after MS, while in those described from Chin and Facchini, HIV infection clearly preceded MS and only one the diagnosis was concomitantly (10-15). Regarding the gender of the patients, six males (including our case) and only one female are reported (Table II), in contrast to the typical finding of female prevalence in MS.

Interestingly, Maruszak et al. (2011) and Chalkley et al. (2014) describe improvement of neurological symptoms and no relapses in patients with MS and HIV infection, after receiving antiretroviral therapy $(11,12)$. The most striking element is that these patients showed no complications and disease progression for a long time, remaining clinically stable, similarly to the clinical status of our patient for the last two years. In 2015 Gold et al., in the largest linkage study undertaken to investigate a possible association between HIV and MS, revealed that HIV infection is associated with significantly decreased risk of developing MS (16).

\section{Discussion}

Our patient is the first clinical case in the literature, whose MS diagnosis significantly proceeds HIV infection with such a big interval. Although his total clinical course cannot be officially considered as a benign type of MS, his disease course is significant for very few relapses and minimal accumulative disability. The accidental result of HIV seropositivity, as well as the persistent stable clinical presentation while on monotherapy with highly active antiretroviral therapy (HAART), led as to investigate whether his clinical stability is associated with either the HIV infection per se, or with the possible effects of the HAART in MS. It is well known that concurrence of MS and HIV infection is uncommon and only six cases (fulfilling the McDonald criteria) have been reported, as presented in Table II.

Our case is the first of an MS patient with a following HIV infection treated with the novel antiretroviral drug ATRIPLA $^{\circledR}$. While on ATRIPLA ${ }^{\circledR}$ treatment, he remains relapse free, neurologically stable, and with undetectable viral load. 
in vivo $31: 1041-1046(2017)$

Table II. Published reports of HIV and MS coexistence, type of MS, and Medications.

\begin{tabular}{|c|c|c|c|c|c|}
\hline Case & Gender & $\begin{array}{l}\text { Age of multiple } \\
\text { sclerosis onset }\end{array}$ & $\begin{array}{c}\text { Type of } \\
\text { multiple sclerosis }\end{array}$ & $\begin{array}{l}\text { Medication } \\
\text { for HIV }\end{array}$ & $\begin{array}{l}\text { Medication for } \\
\text { multiple sclerosis }\end{array}$ \\
\hline Our Case & Male & 24 & Relapsing-Remitting & $\begin{array}{l}\text { Efavirenz/Emricitabine/ } \\
\text { Tenofovir disoproxil fumarate }\end{array}$ & Interferon- $\beta$ \\
\hline Chin et al. 2015 & Female & 34 & Relapsing-Remitting & No information available & No information available \\
\hline Chalkley et al. 2014 & Male & 32 & Multiple Sclerosis-like & $\begin{array}{c}\text { Emricitabine/Tenofovir } \\
\text { Nelfinavir }\end{array}$ & No information available \\
\hline H.Maruszak et al. 2011 & Male & 26 & Relapsing-Remitting & $\begin{array}{c}\text { Nevirapine } \\
\text { Stavudine } \\
\text { Didanosine } \\
\text { Abacavir } \\
\text { Lamivudine } \\
\text { Ritonavir } \\
\text { Indinavir }\end{array}$ & $\begin{array}{l}\text { Corticosteroids } \\
\text { Interferon- } \beta\end{array}$ \\
\hline Sardar et al. 2011 & Male & 35 & Progressive & No information available & $\begin{array}{c}\text { Solumedrol } \\
\text { Oral steroids }\end{array}$ \\
\hline Duran et al. 2004 & Male & 32 & No information available & $\begin{array}{l}\text { Atazanavir/Ritonavir boosted } \\
\text { Lopinavir/Ritonavir boosted }\end{array}$ & No information available \\
\hline Facchini et al. 2002 & Male & 8 & No information available & No information available & $\begin{array}{l}\text { Methylprednisolone } \\
\text { Prednisolone }\end{array}$ \\
\hline
\end{tabular}

MS, Multiple sclerosis; HIV, human immunodeficiency virus; R-R, relapsing-remitting.

It is known, that the mechanism of action of efavirenz is through non-competitive inhibition of the HIV reverse transcriptase (17). Moreover, the mechanism of action of both tenofovir-disoproxil-fumarate (nucleotide reverse transcriptase inhibitor) and emtricitabine (nucleoside reverse transcriptase inhibitor) is based on the intracellular conversion of these drugs to their active metabolites, which competitively inhibit the activity of HIV reverse transcriptase and consequently block viral replication $(17,18)$. In this way, the drug restores the number of $\mathrm{CD}^{+}$lymphocytes interfering with immunemodulation. Regarding our patient, we cannot ignore the fact that fumarate is a component of ATRIPLA ${ }^{\circledR}$ as tenofovirdisoproxil-fumarate. Chalkley and colleagues also report the same clinical effect in their clinical MS-HIV case treated with tenofovir, which contains the fumarate (11).

Fumarate was recently approved by FDA as dimethylfumarate for MS treatment. It exerts its immunomodulatory effect by reducing the expression of cytokines tumor necrosis factor-a (TNF-a), interleukin- $1 \beta$ (IL-1 $\beta$ ), and interleukin-6 (IL-6) in glial cells, and also by mediating a strong antioxidant effect (19-23). Although it is not available in the international literature and we cannot confirm in any way the bioequivalence of these two components, the disoproxilfumarate might somehow act as an immunomodulatory agent, leading to clinical stability. However, this working hypothesis requires extensive research.

An MS-like illness has been previously described in association with HIV-1 infection with a clinical syndrome indistinguishable from MS $(9,10)$. Taking into consideration the primitive criteria of MS in 1989, we cannot be sure that these patients were suffering from MS per se or another demyelinating disease. Reviewing the reports which fulfill the McDonald criteria we can notice that six patients were males (including our case) and only one was female, in contrast to the typical finding of female prevalence in MS. The clinical course of the patients presented was relapsingremitting MS, in the majority of the cases ( 3 cases including ours). Except for one, adult patients received antiretroviral therapy and claimed clinical stability. Interestingly, Maruszak and Chalkley described improvement of MS symptoms and no relapses in their patients after initiation on antiretroviral therapy remaining clinically stable for 12 and 8 years respectively, receiving only HAART $(11,12)$.

Several explanations of the patient's clinical course can be supposed. First, immunodeficiency induced by HIV itself (even in the absence of antiretroviral treatment) may prevent the deterioration of MS. In specific, HIV harms immune-cell homoeostasis and targets a wide range of immune cells $\left(\mathrm{CD}^{+}, \mathrm{CD}^{+}\right)$and signaling pathways overlapping with $\mathrm{MS}$ pathogenesis (24-31). HIV infection selectively depletes $\mathrm{CD}^{+} \mathrm{T}$ cells, and therefore it may be considered protective against the occurrence of MS.

Second, as it is widely accepted, a decrease in regulatory T cells (Treg) drives CNS injury in MS, which is in part mediated by autoreactive $\mathrm{CD}^{+} \mathrm{T}$ lymphocytes, in addition to increased T-helper 17 cells (Th17) and Th1 cells (30). We 
could assume that the available antiretroviral therapies may restore this balance, helping to reduce the inflammatory component.

Another explanation regarding the clinical stability of all patients reported is that antiretroviral medications used to suppress HIV replication, in theory, may suppress other viral pathogens implicated in MS, like Human Endogenous Retroviruses (HERVs) and herpes viruses (32-37).

\section{Conclusion}

In conclusion, our case report highlights the possible pathophysiological interaction between HIV and MS and the likelihood of a positive influence of HIV on the clinical course of MS, a hypothesis that needs to be further investigated. We also suggest that the probable beneficial effects of antiretroviral drugs on the progression of MS should be further explored as they could offer an alternative, apart from conventional, immunomodulatory MS therapy.

\section{Conflicts of Interest}

The Authors declare no conflicts of interest.

\section{References}

1 Lassman H, Bruck $\mathrm{W}$ and Lucchinetti CF: The immunopathology of multiple sclerosis an overview. Brain Pathol 17: 210-218, 2007.

2 Greenberg SJ: Human retrovirus and demyelinating diseases. Neurol Clin 13: 75-79, 1995.

3 Shapshak P, Kangueane P, Fujimura RK, Commins D, Chiappelli F, Singer E, Levine AJ, Minagar A, Novembre FJ, Somboonwit C, Nath A and Sinnott JT: Editorial neuroAIDS review. AIDS 25: 123-141, 2011.

4 Spudich S: HIV and neurocognitive dysfunction. Curr HIV/AIDS Rep 3: 235-243, 2013.

5 Donald KA, Walker KG, Kilborn T, Carrara H, Langerak NG, Eley B and Wilmshurst JM: HIV Encephalopathy: pediatric case series description and insights from the clinic coalface. AIDS Res Ther 12: 2, 2015.

6 Clifford DB and Ances BM: HIV-associated neurocognitive disorder. Lancet Infect Dis 13: 976-986, 2013.

7 Berger JR, Sheremata WA, Resnick L, Atherton S, Fletcher MA and Norenberg M: Multiple sclerosis-like illness occurring with human immunodeficiency virus infection. Neurology 3: 324-329, 1989

8 McDonald WI, Compston A, Edan G, Goodkin D, Hartung HP, Lublin FD, McFarland HF, Paty DW, Polman CH, Reingold SC, Sandberg-Wollheim M, Sibley W, Thompson A, van den Noort S, Weinshenker BY and Wolinsky JS: Recommended diagnostic criteria for multiple sclerosis: guidelines from the International Panel on the diagnosis of multiple sclerosis. Ann Neurol 1: 121$127,2001$.

9 Berger JR, Tornatore C, Major EO, Bruce J, Shapshak P, Yoshioka M, Houff S and Sheremata W, Horton GF and Landy $\mathrm{H}$ : Relapsing and remitting human immunodeficiency virus- associated leukoencephalomyelopathy. Ann Neurol 1: 34-38, 1992.

10 Chin JH: Multiple sclerosis and HIV-1 infection: case report of a HIV controller. Neurovirol 4: 464-467, 2015.

11 Chalkley J and Berger JR: Multiple sclerosis remission following antiretroviral therapy in an HIV-infected man. J Neurovirol 6: 640-643, 2014.

12 Maruszak H, Brew BJ, Giovannoni G and Gold J: Could antiretroviral drugs be effective in multiple sclerosis? A case report. Eur J Neurol 9: 110-111, 2011.

13 Sardar P, Guha P, Roy D and Bandyopadhyay: Multiple sclerosis like demyelination in early HIV infection-A rare presentation: case report and literature review. AIDS Clinc Res 2: 124, 2011.

14 Duran E, Galvez J and Patrignani G: Multiple sclerosis-like illness in a HIV-1 patient J Neurol 9: 1142-1144, 2004.

15 Facchini SA, Harding SA and Waldron RL: Human immunodeficiency virus-1 infection and multiple sclerosis-like illness in a child. Pediatr Neurol 3: 231-235, 2002.

16 Gold J, Goldacre R, Maruszak H, Giovannoni G, Yeates D and Goldacre M: HIV and lower risk of multiple sclerosis: beginning to unravel a mystery using a record-linked database study. $\mathbf{J}$ Neurol Neurosurg Psychiatry 1: 9-12, 2015.

17 US Food and Drug Administration. Antiretroviral drugs used in the treatment of HIV infection Accessed July,12,2006. Available from: https://www.fda.gov/forpatients/illness/hivaids/treatment/ ucm118915.htm

18 Dando TM and Wagstaff AJ: Emtricitabine/tenofovir disoproxil fumarate. Drugs 18: 2075-2082, 2004.

19 Kaufmann DE, Kavanagh DG, Pereyra F, Zaunders JJ, Mackey EW, Miura T, Palmer S, Brockman M, Rathod A, PiechockaTrocha A, Baker B, Zhu B, Le Gall S, Waring MT, Ahern R, Moss $\mathrm{K}$, Kelleher AD, Coffin JM, Freeman GJ, Rosenberg ES and Walker BD: Up-regulation of CTLA-4 by HIV-specific CD4+ T cells correlates with disease progression and defines a reversible immune dysfunction. Nat Immunol 11: 1246-1254, 2007.

20 Schweckendiek W: Behandlung der Psoriasis vulgaris Med Monatsschr 13: 103-104, 1959.

21 Wierinckx A1, Brevé J, Mercier D, Schultzberg M, Drukarch B and Van Dam AM: Detoxication enzyme inducers modify cytokine production in rat mixed glial cells. J Neuroimmunol 166: 132-143, 2005.

22 Scannevin RH, Chollate S, Jung MY, Shackett M, Patel H, Bista P, Zeng W, Ryan S, Yamamoto M, Lukashev M and Rhodes KJ: Fumarates promote cytoprotection of central nervous system cells against oxidative stress via the nuclear factor (erythroid-derived 2)-like 2 pathway. J Pharmacol Exp Ther 1: 274-284, 2012.

23 Das RK, Brar SK and Verma M: Recent advances in the biomedical applications of fumaric acid and its ester derivatives: The multifaceted alternative therapeutics. Pharmacol Rep 68: 404-414, 2016.

24 Koudriavtseva T, Plantone D, Mandoj C, Giannarelli D, Latini A, Colafigli M, Trento E, Cordiali-Fei P and Pimpinelli F: HIV and decreased risk of multiple sclerosis: role of low CD4+ lymphocyte count and male prevalence. J Neurovirol 23: 147-151, 2017.

25 Catalfamo M, Di Mascio M, Hu Z, Srinivasula S, Thaker V, Adelsberger J, Rupert A, Baseler M, Tagaya Y, Roby G, Rehm C, Follmann D and Lane HC: HIV infection-associated immune activation occurs by two distinct pathways that differentially affect CD4 and CD8 T cells. Proc Natl Acad Sci USA 50: 19851-19856, 2008. 
26 Lempicki RA, Kovacs JA, Baseler MW, Adelsberger JW, Dewar RL, Natarajan V, Bosche MC, Metcalf JA, Stevens RA, Lambert LA, Alvord WG, Polis MA, Davey RT, Dimitrov DS and Lane HC: Impact of HIV-1 infection and highly active antiretroviral therapy on the kinetics of $\mathrm{CD}^{+}{ }^{+}$and $\mathrm{CD} 8^{+} \mathrm{T}$ cell turnover in HIV-infected patients. Proc Natl Acad Sci USA 25: 1377813783, 2000.

27 Koenig S, Gendelman HE, Orenstein JM, Dal Canto MC, Pezeshkpour GH, Yungbluth M, Janotta F, Aksamit A, Martin MA and Fauci AS: Detection of AIDS virus in macrophages in brain tissue from AIDS patients with encephalopathy. Science 4768: 1089-1093, 1986.

28 Wiley CA, Schrier RD, Nelson JA, Lampert PW and Oldstone MB: Cellular localization of human immunodeficiency virus infection within the brains of acquired immune deficiency syndrome patients. Proc Natl Acad Sci USA 18: 7089-7093, 1986.

29 Nadal M, Mas PJ, Blanco AG, Arnan C, Solà M, Hart DJ and Coll M: Structure and inhibition of herpes virus DNA packaging terminase nuclease domain. Proc Natl Acad Sci USA 107: 16078-16083, 2010.

30 Hunt PW, Brenchley J, Sinclair E, McCune JM, Roland M, Page-Shafer K, Hsue P, Emu B, Krone M, Lampiris H, Douek D, Martin JN and Deeks SG: Relationship between T cell activation and $\mathrm{CD}^{+}{ }^{+} \mathrm{T}$ cell count in $\mathrm{HIV}$-seropositive individuals with undetectable plasma HIV RNA levels in the absence of therapy. J Infect Dis 1: 126-133, 2008.

31 Geffin R and McCarthy M: Innate immune responses to HIV infection in the central nervous system. Immunol Res 57: 292$302,2013$.
32 Artemiadis $\mathrm{AK}$ and Anagnostouli M: Apoptosis of oligodendrocytes and post-translational modifications of myelin basic protein in multiple sclerosis: possible role for the early stages of multiple sclerosis. Eur Neurol 2: 65-72, 2010.

33 Koros C, Ioannidis A, Acquaviva T, Zoga M, Nikolaou C, Chatzipanagiotou S, Kossyvakis A, Anagnostouli M: HSV1 and 2 detection in the CSF of multiple sclerosis patients by real-time PCR. In Vivo 6: 1201-1205, 2014.

34 Belshaw R, Katzourakis A, Paces J, Burt A and Tristem M: High copy number in human endogenous retrovirus families is associated with copying mechanisms in addition to reinfection. Mol Biol Evol 22: 814-817, 2005.

35 Perron H, Dougier-Reynaud HL, Lomparski C, Popa I, Firouzi R, Bertrand JB, Marusic S, Portoukalian J, Jouvin-Marche E, Villiers CL, Touraine JL and Marche PN: Human endogenous retrovirus protein activates innate immunity and promotes experimental allergic encephalomyelitis in mice. PLoS One 8 : e80128, 2013.

36 Van der Kuyl AC: HIV infection and HERV expression: a review. Retrovirology 9: 6, 2012.

37 Johnston JB, Silva C, Holden J, Warren KG, Clark AW and Power C: Monocyte activation and differentiation augment human endogenous retrovirus expression: implications for inflammatory brain diseases. Ann Neurol 50: 434-442, 2001.

Received July 10, 2017

Revised July 26, 2017

Accepted August 1, 2017 